Time Travel 
This page intentionally left blank 


\section{Time Travel}

\section{The Popular Philosophy of Narrative}

David Wittenberg

F O R D H A UNIVERSITY PRESS

NEW YORK 2 O I 3 
Copyright (C) 2013 Fordham University Press

All rights reserved. No part of this publication may be reproduced, stored in a retrieval system, or transmitted in any form or by any means-electronic, mechanical, photocopy, recording, or any other-except for brief quotations in printed reviews, without the prior permission of the publisher.

Fordham University Press has no responsibility for the persistence or accuracy of URLs for external or third-party Internet websites referred to in this publication and does not guarantee that any content on such websites is, or will remain, accurate or appropriate.

Fordham University Press also publishes its books in a variety of electronic formats. Some content that appears in print may not be available in electronic books.

Library of Congress Cataloging-in-Publication Data

Wittenberg, David.

Time travel : the popular philosophy of narrative / David Wittenberg. - Ist ed.

p. $\mathrm{cm}$.

Includes bibliographical references and index.

ISBN 978-0-8232-4996-I (cloth : alk. paper)ISBN 978-o-8232-4997-8 (pbk. : alk. paper)

I. Time perception in literature. 2. Time travel in literature. 3. Narration (Rhetoric) 4. LiteraturePhilosophy. I. Title.

$\mathrm{PN}_{5} 6 . \mathrm{T}_{5} \mathrm{~W}_{5} 820 \mathrm{I} 3$

8o9'.93384-dc23

2OI2O29IOI

Printed in the United States of America

$\begin{array}{lllllll}\text { I5 } & \text { I4 I } 3 & 5432 & \text { I }\end{array}$

First edition 
for Lara and Leela 
This page intentionally left blank 